\title{
Phraseological Nature of Terminology Combinations in Russian Dialects (Through Don Dialects)
}

\author{
Nadezhda M. Loktionova, Lidia K. Alakhverdieva, Olga A. Fomina*, Irina A. Kuzminova, and Irina A. Zubkova \\ Department of Sciences Foreign languages, Don state technical university, Academy of construction and architecture, Rostov-on-Don, \\ Russia
}

\begin{abstract}
Areal study of the Don territory provides researchers with the evidences of ethnic culture. Uniqueness of the semantic development of Don dialect phraseology in a modern research paradigm is perceived as a reflection of a national language background of linguistic-cultural community. A special mention must be made with regards to a particular nature of linguistic culture and dialectic terminology of Don dialects. When covering the role of terminology phrases in a dialect and the appropriateness of classifying them as dialect phraseological units, their continual relationship with ethnic and linguistic factors are worth mentioning.
\end{abstract}

Studying and describing the distinctive features of Russian dialects contributes to learning Russian language as a whole. Problems of regional linguistics are under constant review of the researchers by virtue of the fact that they have a strong connection to Russian psyche. A colloquial language being the subject for scientific research is a cultural and speech mark of a native land.

Dialect assessment of a nationwide Russian language portrays a creative perception of the world. Demonstration of the creative nature in the language of dialect speakers, of Don areal in particular, characterizes dialectic terminology generation.

Russian vernaculars are the indicators of the condition of a language in the past and at present. The remarkable thing is that vernacular terms having a nominative function are filled with the inner form in the system of dialectic terminology, which distinguishes them from the terminological combinations of the literary language.

A linguistic and cultural interpretation of a term's phrase semantic field in dialect phraseology of Russian Don dialects is manifested in vernacular compound terms. Determination of the denotative fund of Don dialect phraseology clarifies its semantic characteristic. A part of vernacular compound terms of a dialect plan should be admitted to enter a phraseological dialects system in contrast to scientific terms of a literary language

Semantic and, to a greater extent, figurative focus of the dialects lexis and phraseology at an early stage of its analysis, a so called lexicographical stage, was rather specified by the following: the category comprises such fundamentals as environmental conditions, housekeeping, cattle breeding, gardening, field work, forestry, housebuilding, welfare, kinship relationship, medical treatment and calendar cults.

Consequently, dialect phraseology alongside with lexis might have characterized peasant's daily life and it is noticed by many dialects researchers. Additionally, the nominative function of terminology units includes a cumulative function comprising the knowledge of a linguistic and cultural nature.

Extratextual factors explain the plurality of Don dialects terminology units denoting natural phenomena. The discourse of Russian Don dialects speakers inhabiting agricultural zones near the river Don and its tributary comprises 21 naming units denoting river water with regards to its conditions in different seasons, one or another set of wind. The dialectic phraseological units denoting the quality of water and wind are as follows: voronezhskaya voda (Voronezh water) has the meaning of "cold high water from the Upper Don" [5], georgitskaya voda (Georgian water) denotes "warm water" [5], muzhitschiy veter/veter s/iz muzhikov (men's wind/wind from men) has the connotation of "cold North-Wester blowing from the Voronezh Region" [5], veter s pol dnya (wind starting past noon) is "a south wind" [5], etc.

A distinguishing characteristic of this group is an event-related, temporal or geographic information belonging to the category of dialectic phraseological units (e.g. khomutovskaya voda is "the high water on Don in 1849", semibabskaya voda is "the high water on Don in the XIX century", krasnochekovskaya voda is "the high water on Don in 1786" [5], semnadtsataya voda (the seventeenth water) is "the high water on Don in 1917" [5], etc.) or the ones which can be traced in its inner form, e.g. muzhitschiy veter/veter s/iz muzhikov (men's wind/wind from men got this name because it blew from the place of living of muzhikov (men) who

*Corresponding author: lelik8181@list.ru 
were northern (Voronezh) neighbours, not the Kozaks but Russians, moskovskaya voda (Moscow water) denoted the water brought by the high water from the northern Moscow direction, georgitskaya voda (Georgian water) named the third warm Don overflow happened on $6^{\text {th }}$ May (23 $3^{\text {rd }}$ April in the Julian calendar), which is the feast of St. George (Egoriy Veshniy), etc.

A group of dialect phraseological units denoting natural phenomena are noted by such a scarce phenomenon inherent in scientific compound terms as synonymity, e.g. voronezhskaya voda (Voronezh wate) and moskovskaya voda (Moscow water) denote "cold high water from the Upper Don" [5], kozi/kozli begut (goats run) [5], poldny igrayut (afternoons play) [5] and parusa/parusi begut (canvases flow) [5] are used to talk about "the air movement on a hot day".

Terminology dialectic phraseological units denoting domestic appliances, peasant household, time of day, workflow, etc. are united into a nominative group of phraseological units as opposed to the group of expressive and figurative phraseological units. Such phraseological units name specific things, phenomena, processes, etc., are generated by people for the precise identification of certain objects [1]. A distinguishing feature of terminological combinations being the correspondence to a singular object or event without rising to the function of generalization is not restricted to the quality indicators of dialectic household terminology where a set of a term attributes and phraseological unit attributes can be traced [3].

Generation of the inner form of a terminological combination in consequence of a metaphorical shifting based on the similarity of externalities, forms or the performed functions of the objects and phenomena being denoted with the objects and phenomena of the real life, approximates it to a phraseological unit.

The tendency of scientific terms towards emotional neutrality is exchanged with the emotional expressiveness with regards to dialectic household terminology of the phraseological nature. For example, in the case of such dialectic terminological phraseological units as plants names medvezhyia lapka (a small paw of a bear) and teschin yazik (mother-inlaw's tongue (mother-in-law's plant)), the metaphorical shifting is based not only on the experience of overwatching the world around but also on positive or negative emotions of language speakers.

The analysis of dialectic terminological phraseological units as well as studying all dialectic phenomena against the background of correlating of the countrywide language and dialects brings scientists to the conclusion that the charge of the inner form of dialectic terminological combinations is higher than the ones of a literary language, which defines their phrasemic status and approximates them to phraseology. The stated distinguishing feature of dialectic terminological phraseological units is stipulated by a distinctive functional feature of dialects being an oral form of existence. Another distinctive feature of dialects being the predominance of aspect categories over the generic ones and aiming at specification also stipulates the fact of the quantitative predominance of terminological combinations in phraseological systems of dialects. As well, the quantitative predominance of dialectic phraseological units of a terminological nature stipulates their ability to range despite their monosemy, e.g. grey/severe shchi means "shchi (Russian cabbage soup) without meat". The existence of variants also distinguishes dialectic phraseological units from the countrywide ones including both scientific and household terms.

The opposition of a scientific term dialectic terminological phraseological unit can be demonstrated by the table 1 .

Table 1. Distinctive features of TDDPHU and scientific term.

\begin{tabular}{|c|c|c|c|c|}
\hline $\begin{array}{l}\text { Feature } \\
\text { of a linguistic } \\
\text { unit }\end{array}$ & : & 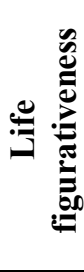 & 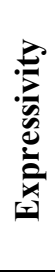 & 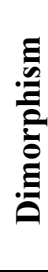 \\
\hline $\begin{array}{c}\text { compound scientific } \\
\text { term }\end{array}$ & + & - & - & - \\
\hline $\begin{array}{c}\text { dialectic } \\
\text { terminological } \\
\text { phraseological units }\end{array}$ & + & + & + & + \\
\hline
\end{tabular}

With regards to the attributes characteristic of dialectic terminological phraseological units the attribute of monosemy essential for all terminological phrases enables to divide the group of household dialectic terminological phraseological units into topical units denoting rites, games, plants, animals and birds, natural phenomena, household items, work processes on the basis of phrase-semantic field.

A group of terminology combinations denoting games is rather numerous in various dialects of the Russian language. According to the Dictionary of Russian Don dialects this group includes 40 units. This entire group can be considered as a dialectic one due to the dialectal expressions included in it. The examples of such dialectal expressions are as follows: to play mulga (mulga is a type of hockey with a ball [5]), to play cabbage stalk (cabbage stalk is a game with a ball [5]), to play knuckles (knuckles is a crap game [5]). Each terminology unit includes information about one or another traditional game, its peculiarities. The connotation of dialectal expressions cleared up via dictionaries proves that these combinations were formed in terms of the free ones: along with the names of the games, the enumerated attributes can name their attributes, e.g. mulga is "a wooden stick with a thickened edge used for playing games", cabbage stalk is "a stick for the game with a wooden ball", knuckle is "a die made of a domestic animals' joint".

Terminological units of non-phraseological nature belonging to the mentioned topic subgroup can be the basis of forming dialectic phraseological units, e.g. to play idanchiki means 1) "to play dice"; 2) "to be a child" [5]. 
The second group of compound household terms in Don dialects comprises 56 units denoting ritual procedures. 47 of them can be regarded as terminology Don dialects phraseological units (TDDPHU). Their phraseological nature is stipulated by figurativeness, allegorical character of the rituals, holy day, folk festivals, parties devoted to seeing off the people joining military service, which were formed for centuries. The examples are as follows: voditj medvedya (lead a bear) means "thronging in hordes (used to talk about people celebrating a wedding)" [5], posladitj dorozhku (to sweeten the road) has the connotation "to toast to a happy life (of newlyweds)" [5]; pestraya nedelya (a many-coloured week) is "a week of a meat eater with the fasting-days on Wednesday and Friday" [5]; pletenj plesti (to wattle) means "to sing and dance in a ring", stremennaya rjumka (a stirrup cup) denoted "the last cup of alcohol drink taken before joining a military service" [5], etc.

This productive group of TDDPHU is represented by two variant rows, e.g. zalivatj/zavivatj ovin (to extinguish with water/to wind hey) means "to jump over the burning hey at the end of a wedding rite" [5], obmivatj/razmivatj ruki (to wash/wash out hands) has the connotation "to award a midwife for the favourable outcome of labor" [5]. The ritual of refusal during the ritual of marriage proposal is a kind of folk mockery of an unsuccessful fiancé, which is denoted by three TDDPHU: podnesty garbuz (to give a pumpkin), pritsepitj chajnik (to attach a kettle), navyazatj kotelok (to fasten a pot) [5].

As it was stated earlier, a group of household terminology TDDPHU is distinguished by a bright extra linguistic loading. The most detailed extra linguistic information is inherent to wedding TDDPHU, while it is this ceremony which is developed in great details and stages by many generations. Terminology of a wedding rite gradually reveals its essential ritual procedures. About 50 TDDPHU present the plot of a ritual. A family council devoted to shaping a son's destiny gathers all relatives to share advice because a gang is successful in catching a fish in water and hunt a weasel [4]. To hunt a weasel means to match a fiancée. "We are kind people say matchmakers in the house of a young lady - not wicked, not the robbers but visitant hunters, we hunted a wild animal - a weasel and a fox; ... frighten the weasel away and followed the scent, and the scent brought us to your house, now we can see that the weasel is your daughter, a bonny lass" [4].

Symbolic davanje ruki (giving a hand) as an expression of fiancée's parents agreement occurred when the matchmakers from the side of a fiancé came to get a long-awaited answer bringing the bread and salt of hospitality. Fiancée's father and mother gave a hand wrapped in a dress's flap or a kerchief and said the following words: "Good luck on your journey, I wish you well!" If a hand was not wrapped in a dress's flap or a kerchief when being given, in former times it was considered to be a sinister omen. Anciently, people inhabiting the territories near Don supposed that an unwrapped hand was a symbol of poverty [4].

Wedding ritual phraseology and the essential ritual texts and folk songs make up a bright and ethnically marked part of the folk art. A group of so-called ritual dialectic phraseological units represent a unified complex but the development of the semantics of these units pass through a different number of phases of the phase forming process. A large part of ritual units denote actual ritual procedures. Sometimes it is a generic term of a part of a wedding rite, e.g. pomolki igratj means "to celebrate an engagement" [5], predlog delatj denotes "make a proposal of marriage" [5]. However, rather frequently even a part of a wedding rite is called metonymously through a certain action. The names of some actions of this group become symbolic. An example of this type of formations on the basis of free combinations is phraseological units, e.g. vezti podushki (to bring pillows) means "to bring a fiancée's dowry to a fiancé's house" [5], nadevatj kolpak (to put on a cap) denotes "to put on a cap on a topknot as a symbol of becoming a married woman in the near future in contrast to a girl-fiancée" [5], klastj metu (to put a mark) means "to mark a fiancé and a fiancée by putting presents on a shoulder" [5].

As it stands, ritual TDDPHU in contrast to free combinations homonymous to them contain references to actions in their semantics. These references gain a special meaning only under the circumstances of a ritual and dictate the sequence of actions, necessary behavior of certain participants of a ritual, time of a ritual (nadevatj kolpak (to put on a cap) - Who? When? With what objective?).

The brightest part of a ritual is pageants. The meaning of free combinations being the base for ritual units contains only the name of the initial part of a ritual in the case under consideration. A phraseological meaning of a unit includes enacted ritual stages. The meaning of terminology Don dialects phraseological unit vesjeloje utro (a merry morning) contains not only the reference to the first morning after the wedding but also to the reason of merriment being the following: a fiancée's mother is given a saucer with high cranberry symbolizing virginity as a token of a fiancée's virginity [5].

The next stage of forming the semantics of a terminology Don dialects phraseological unit is that a symbolic phraseological meaning of the given units is kept in a situation description even in the case of not committing an action. Afterwards, it is possible to widen the units' phraseological meanings accompanied by the enlargement of the usage area, e.g. the phrase pritsepitj, privyasatj, podvesitj schajnik (to attach, tie, hang a kettle) has the following meanings: 1) to turn down a marriage proposal, 2) to break off with a friend or an acquaintance [5], and the phrase razmivatj ruki (to /wash out hands) has the following connotations: 1) to award a midwife for the favourable outcome of labor, 2) to celebrate an event drinking alcohol [5]. In this case a unit from the category of TDDPhU is transmitted into the category of nonterminological units.

It is worth mentioning that ritual terminology phraseological units of Don dialects are distinguished from other dialects only by a set of object and procedural symbols. In respect of the stages of their semantics development, we can say that these stages are common 
for the units of diverse dialects of Russian language. A group of Don dialect units denoting plants is also of the utmost interest. Actually, all of them are TDDPhU. Dialect phraseological units are greatly represented in the inter-dialectal interaction.

Properly nominative TDDPhU denoting the fundamentals of flora and fauna are mostly the constituents of a general dialectic fund because they are generated with regards to unified schemes of semantic modeling on the basis of certain general, logical and associative processes of a human reasoning.

A terminological group denoting time of day is characteristic for Don dialects as well. All the units of this group represent dialects phraseological units.

Darkness hours are determined by crowing (produced by cocks): the phrase the first cocks was used to talk about a midnight [5], the second cocks - about 2 a.m. [5], the third cocks - about a dawn [5].

An old vernacular tradition is noted in the abovementioned dialects phraseological units. F.I. Buslaev states that individual words of the ancient epoch have a nature of a greater figurativeness; equally, an idea in entire phrases is expressed vividly in an objective correlative rather than abstractedly [2]. For instance, hens or crowing are mentioned instead of a dawn [2]. With the objective to explain poetical expressions F.I. Buslaev wrote about the word kuroklik on the basis of the examples from the "The Song of Igor's Campaign" hen's or cock's cry is of an utmost importance in the part about Vseslav because Vseslav had to prowl "in the guise of a wolf' to escape from Kiev to Tmutorokan "before the cocks", i.e. till all hours. Kuroklik or just hens denoted midnight or dawn in the olden times [2].

The periods of the daylight hours also have a precise connotation in TDDPhU, e.g. rannije zavtraki (early breakfasts) mean "early morning, the time of the sun's appearance" [5], telyachja pora (a calfish period) denotes "chilly time in the morning" [5], solntse $v$ zavtrakah (sun in breakfasts) has the connotation of "position of sun from 8 to 9 a.m." [5], pozdnije zavtraki (late breakfasts) means "late morning, from 9 to 10 a.m." [5], svinyachji poldni (pigs' middays) is "the period from 9 to 10 a.m." [5], solntse $v$ dubu (sun in oak), solntse $v$ obedah (sun at dinnertime) is "the position of sun at noon" [5], solntse $v$ poldyon (sun at midday) is "an afternoon sun" [5], solntse v poldni (sun at middays) is "the sun around 3 to 4 p.m." [5], telyachje vremya (a calfish time) is "shank of the evening" [5].

Such a precise division and naming of the time of day is explained by a great importance of the light day for the country inhabitants. Peculiarities of a workflow and household items are named the terminology units of phraseological nature.

The fact that terminology units are included in the fund of Don dialectic phraseology enables to use them when developing a course of dialectology for being taught in higher education institutions, namely, a special course of study on phraseology and phrase formation. This study material can be also used for creating a bank of Don dialectic phraseology and a bank of general Russian phraseology. The collected material can be applied to create a complete phraseological dictionary of Russian Don dialects.

Thematic diversity of household dialectic phraseology units (ritual dialectic phraseology units, dialectic phraseology units denoting flora and fauna, dialectic phraseology units denoting natural phenomena and dialectic phraseology units denoting workflow and the items of work and household), their ability to vary and be interchangeable distinguishes TDDPhU from the terms of national language with regards to figurativeness and level of information enclosed in the inner form of dialectic phraseology units. Generation of terminology combinations in dialectic phraseology speaks for a high activity of a nation with regards to linguistic creativity.

The major conclusion, which the study of the semantic fields of TDDPhU leads to, and which can be drawn in view of the study under consideration, is that they reflect two directions in their semantics. On the one hand, they contain ethnically specific information which manifests itself both in the meanings of the units and in the figurative base and covers the way of living of the Don Cossacks; on the other hand, Don dialects being the dialects of the secondary formation bear the impress of the phraseological system of other dialects and general national phraseology.

Anthropocentric nature of the study of the terms of a phraseological nature, clarification of an indirect reference of one or another terminology unit included in Don dialects reveals the Don region's history and culture noted in the language and, what is very important, reach in associative imagination which turns household units of the language into expressive means of language.

\section{References}

1. O. S. Ahmanova, Dictionary of linguistic terms (M., 1966)

2. F.I. Buslaev About the teaching of the native language (L., 1941)

3. A.I. Fedorov Russian phraseology and its study by sources: Dis. ... Doct. philol. Sciences (Novosibirsk, 1972)

4. Kh.I. Khlopov Wedding ceremonies. Unfinished manuscript ( GARO, f. 55, op. 1, unit. 740)

5. SRDG: Dictionary of Russian Don dialects / Otv. Ed. V.S. Ovchinnikov (Rostov n / a: RSU, 1975 1976. 1-3)

6. V.B. Gulida Conference "Folk Linguistics": a view of native speakers on the language (M., Q.L. 5, 2013)

7. S.D. Shelov, A.E.Tsumarev III International Symposium "Terminology and Knowledge" (M., Q.L. 1, 2013)

8. Evolution of values in languages and cultures / Otv. Ed. I.A. Sedakova (M.,Q. L. 2, 2013)

9. E.L. Berezovich On modern problems of semanticomotivational reconstruction of people's toponymy (M., Q.L. 2, 2014) 
10. N.M. Stoynova "International conference" Russian language: constructive and lexical-semantic approaches (M., Q. L. 2, 2014)

11. L.B. Savenkova Proverb, proverb and paremia as terms of philology, Phil. B. of the RSU $(\mathbf{1}, 1997)$

12. L.B. Savenkova Paremia and the linguistic sign, Phil. B. of the RSU $(1,2002)$

13. L.B. Savenkova Poetics of Sholokhov's creativity in ethnolinguistic and linguocultural comprehension, Izv. of SFedU. Ph. S. (1, 2016)

14. L.B. Savenkova Negative comparison in the semantic structure of Russian paremias., Ph. and C., $(40,2015$.

15. N.V. Kabinina II International Conference "Ethnolinguistics. Onomastics. Etymology" (M., Q. L. 3, 2013)

16. V.I. Suprun VIII International Conference "Onomastics of the Volga Region" (M., Q. L., 3, 2013)

17. V.B. Gulida Conference "Folk Linguistics": a view of native speakers on the language" (M., Q. L., 5, 2013) 